10. Cotton P, Jackson H (eds). Early intervention and prevention in mental health. Melbourne: Australian Psychological Society, 1996.

11. NHS Centre for Reviews and Dissemination. Effective health care: mental health promotion in high risk groups. FT Health Care, York: University of York, 1997.

12. Olds D, Eckenrode J, Henderson C, Kitzman H, Powers J, et al. Long term effects of home visitation on maternal life course and child abuse and neglect. Fifteen year follow-up of a randomised trial. JAMA 1997; 278: 637-643.

13. Kitzman H, Olds D, Henderson C, Hanks C, et al. Effect of prenatal and infancy home visitation by nurses on pregnancy outcomes, childhood injuries, and repeated childbearing. A randomised controlled trial. JAMA 1997; 278: 644-652.

14. MacDonald G, Roberts $\mathrm{H}$. What works in the early years? Effective interventions for children and their families in health, social welfare, education and child protection. Part III. Essex, UK: Barnados, 1995.

15. Schweinhart L, Weikart D. The High/Scope Perry Pre-school program. In Price R, Cowen E, Lorion R, Ramos-McKay J (eds). 14 ounces of prevention. Washington: American Psychological Association, 1988.

16. Sanders M, Markie-Dadds C. Triple P: A multilevel family intervention program for children with disruptive behaviour disorders. In Cotton P, Jackson H (eds). Early intervention and preventive mental health applications of clinical psychology. Melbourne: Australian Psychological Society, 1995.

17. Bloom B, Hodges W, Calderwell R. A preventive intervention for the newly separated. Am J Orthopsychiatry 1982; 55: 9-26.

18. Bloom B, Hodges W, Calderwell R. A preventive program for the newly separated: initial evaluation. Am J Community Psychol 1982; 10: 251-264.

19. Bloom B, Hodges W, Kern M, McFaddin S. A preventive intervention programme for the newly separated: final evaluations. Am J Orthopsychiatry 1985; 55: 9-26.

20. Caplan R, Vinokur A, Price R, Van Ryn M. Jobseeking, reemployment and mental health: a randomised field experiment in coping with job loss. J Appl Psychol 1989;74: 759-769.

21. Vinokur A, Price R, Caplan R. From field experiences to programme implementation: assessing the potential outcomes of an experimental intervention programme for unemployed persons. Am J Community Psychol 1991; 19: 543-562.

22. Vinokur A, Price R, Schul Y. Impact of the JOBS intervention on unemployed workers varying in risk for depression. $A m$ J Community Psychol 1995; 23: 39-74.

23. Helgason L. Twenty years' follow-up of first psychiatric presentation for schizophrenia: what could have been prevented? Acta Psychiatr Scand 1990; 81: 231-235.

24. Loebel AD, et al. Duration of psychosis and outcome in first-episode schizophrenia. Am J Psychiatry 1992; 149: $1183-1188$.

25. National Health and Medical Research Council. Depression in young people. Clinical practice guidelines. Canberra: Australian Government Publishing Service, 1997.

26. Human Rights and Equal Opportunity Commission. Human rights and mental illness: Report of the national inquiry into the human rights of people with mental illness. Canberra: Australian Government Publishing Service, 1993.

\title{
COMMENT: PROMOTING MENTAL HEALTH IN NSW
}

Peter Sainsbury

Division of Population Health,

Central Sydney Area Health Service

$\mathrm{M}$ any readers would, like me, have been disappointed by the scant regard given to mental health promotion in both Mental health goals and targets and Strategies for health gain. ${ }^{1,2}$ Consequently, it is extremely pleasing that the NSW Centre for Mental Health has begun to address the deficit. ${ }^{3}$

The centrepiece of Mental health promotion in NSW is the mental health promotion framework which, firstly, recognises the importance of both promoting positive mental health and preventing mental health problems and disorders (the former having been almost totally ignored by Australian health policy and services for far too long) and, secondly, proposes using the five familiar approaches from the Ottawa Charter to develop strategies to address these two overlapping issues. ${ }^{4}$ Even the most dedicated proponents can be overwhelmed at times by the enormity of the task of reducing poverty, increasing equity or improving mental health. Consequently, a model that provides a comprehensive, structured approach to the problem can suggest opportunities for action and allow workers to see how their small contribution fits into the larger picture. I find this latter aspect of good models encouraging, even empowering. There are, however, other useful and noteworthy contributions in Mental health promotion in NSW: the definition of a dozen slippery terms, such as 'mental health promotion' and 'positive mental health', the elaboration of 11 underlying principles of mental health promotion' and the identification of the need to build the information, infrastructure and resource bases in order to develop mental health promotion in NSW.

Why, then, has the promotion of positive mental health lagged so far behind the promotion of physical health, the management of mental illness and even the prevention and early detection of mental illness?

Firstly, acceptance of the existence of positive health (as opposed to good health being simply the absence of disease) has proven even more problematic for mental than physical health. Without acceptance of the idea of positive mental health, the development of a widely accepted conceptual definition is impossible, and the measurement of positive mental health is unthinkable. Postmodernism may hold sway in some intellectual circles, but rational positivism (or at least its rhetoric) still rules in the politics and management of health care, and in the absence of measurement, progress is difficult. 
of Health is currently reviewing the skin penetration guidelines and will incorporate advice to assist the industry to address these and all relevant infection control issues. Finally, enforcement of the guidelines may be required for repeatedly noncompliant operators.

Tattooists were not included in this survey owing to their small number in the areas surveyed. As was evident from Davis's recent letter on tattoos and hepatitis $\mathrm{C}$, there seems to be a dearth of information on infection control practices of NSW tattooists. ${ }^{15}$ A statewide survey of tattooists would be useful.

\section{ACKNOWLEDGMENTS}

We gratefully acknowledge the assistance of the following Public Health Unit staff: Steve Hatzi, Lorraine Winchester, Danielle Edwards and Trudi Coutts.

\section{REFERENCES}

1. Benenson A. Control of communicable diseases in man. Washington: American Public Health Association, 1990.

2. Reed B, Barrett A, Smith M. The relationship of tattooing to hepatitis B virus exposure [letter] Aust NZ J Med 1985; 15: 769-770.

3. Thompson S, Hernberger F, Wale E, Crofts N. Hepatitis C transmission through tattooing: a case report. Aust $N \mathrm{Z} \mathrm{J}$ Public Health 1996; 20: 317-318.

4. Abildgaard N, Peterslund N. Hepatitis C virus transmitted by tattooing needle [letter]. Lancet 1991; 338: 460.

5. Pavli P, Bayliss J, Dent O, Lunzer M. The prevalence of serological markers for hepatitis B virus infection in Australian Naval personnel. Med J Aust 1989; 151: 71-75.

6. Kent G, Brodum J, Keenlyside R, LaFazia L, Scott H. A large outbreak of acupuncture associated hepatitis B. Am J Epidemiol 1988; 127: 591-598.

7. Backinger C. Skin penetration workers: a critical link in the AIDS education chain? AIDS Educ Prev 1989; 1: 31-38.

8. Turkeltaub S, Habal M. Acute Pseudomonas chondritis as a sequel to ear piercing. Ann Plastic Surg 1990; 24: 279-282.

9. Cumberworth V, Hogarth, T. Hazards of ear piercing procedures which traverse the cartilage: a report of Pseudomonas perichondritis and review of other complications. Br J Clin Pract 1990; 44: 512-513.

10. Skin penetration guidelines. Sydney: NSW Health Department, 1991.

11. Clinical reporting systems, version $2.51 \mathrm{~b}$ [computer program]. Sydney: Clinical Reporting Systems, 1990.

12. SAS System for Personal Computers, Release 6.03. Cary, NC: SAS Institute Inc., 1988.

13. Epi Info Version 5.00. Centers for Disease Control, Atlanta, Georgia, 1990.

14. AS4187. Cleaning disinfecting and sterilizing reusable medical and surgical instruments and equipment and maintenance of associated environments in health care facilities. 2nd edn. Sydney: Australian Standards Association, 1998

15. Davis A R. Tattoo parlours and hepatitis $C$ virus infections. Med J Aust 1995; 163: 556-557.

\section{COMMENT: PROMOTING MENTAL HEALTH IN NSW}

continued from p. 46

Secondly, because mental health is so heavily influenced by social structures and processes at the interpersonal, community, national and international levels, the promotion of positive mental health is, more than any other aspect of health promotion, outside the domains of control and influence of traditional health care services. When promoting mental health, it is necessary but not sufficient to ask: How can we enable people to think fewer negative thoughts (compare this with 'smoke less') or be nicer to their neighbours (compare with 'exercise more'). We must also ask: What sort of society (locally, nationally and internationally) do we want to live in? For instance, do we want

- to destroy the history, culture, environment and selfesteem of some groups to promote the interests of others?

- to create social policies which make it all but impossible for many to feel part of, and participate fully in, society?

- to place all the blame on individuals when a child is battered to death, rather than examine the social conditions that create child abuse?

- to exploit workers in developing countries to satisfy our desire for consumer goods?

- to tolerate, and even sometimes promote, the use of violence as a means of solving international disputes?

These are intensely political questions. To promote the mental health of an individual, we must create societies in which social structures and processes promote positive mental health for everyone, not just a few. Mental health promotion in NSW is a welcome start for the health sector in NSW. We must be careful, however, not to neglect the role played by our own health care and employment practices in promoting and undermining mental health.

\section{REFERENCES}

1. Commonwealth Department of Human Services and Health. Better health outcomes for Australians. National goals, targets and strategies for better health outcomes into the next century. Canberra: Australian Government Publishing Services, 1994.

2. NSW Mental Health Expert Party. NSW mental health goals and targets and strategies for health gain. Sydney: NSW Health Department, 1995.

3. Scanlon K, Williams M, Raphael B. Mental health promotion in NSW: conceptual framework for developing initiatives. Sydney: NSW Health Department, 1997.

4. Ottawa Charter for Health Promotion. World Health Organization and Canadian Public Health Association; International Conference on Health Promotion; 1986 November 17-21; Ottawa. 